\title{
Ruling Divisions: The Politics of Brexit
}

\author{
Tim Haughton (1), University of Birmingham \\ t.j.haughton@bham.ac.uk
}

\begin{abstract}
Brexit in History: Sovereignty or a European Union? By Beatrice Heuser. London: Hurst \& Company, 2019. 304p. \$30.00 cloth.

Brexitland: Identity, Diversity and the Reshaping of British Politics. By Maria Sobolewska and Robert Ford. Cambridge: Cambridge University Press, 2020. 408p. \$64.99 cloth, \$19.99 paper.

Framing Risky Choices: Brexit and the Dynamics of High Stakes Referendums. By Ece Özlem Atikcan, Richard Nadeau, and Éric Bélanger. Montreal: McGill-Queen’s University Press, 2020. 248p. \$120.00 cloth, \$32.95 paper.

The Left Case for Brexit: Reflections on the Current Crisis. By Richard Tuck. Cambridge: Polity, 2020. 200p. \$59.95 cloth, \$19.95 paper.
\end{abstract}

The Referendum in Britain: A History. By Lucy Atkinson, Andrew Blick, and Matt Qvortrup. Oxford: Oxford University Press, 2020. 256p. \$85.00 cloth.

$\square$ erhaps the most surprising thing about Brexit is that we should not have been surprised at all. The fuel had been amassing for decades. All it really needed was a spark, and that was duly provided by David Cameron. In calling a referendum he struck the match that unleashed a fire whose flames not only forced him to flee 10 Downing Street but also ushered in a period of political imbroglio in British politics characterized by leadership elections, an early general election, unusual political alliances, Supreme Court battles, long parliamentary debates, indecisive votes and humiliating defeats for the government, large-scale demonstrations, the resignation of another prime minister, the prorogation of Parliament, and yet another early general election. Even after the United Kingdom's formal departure from the European Union on January 31,2020 , the turmoil continued up to and beyond the end of the transition period in December 2020.

Scholarship has already served up several insightful accounts from eminent political scientists of the referendum vote on June 23, 2016, helping explain to a puzzled academic community and punditocracy how its outcome could have happened. Many of these accounts focus on the vote itself, with their number crunching leading them to stress the salience of immigration and a "complex and crosscutting mix of calculations, emotions and cues" (Clarke, Goodwin, and Whiteley, 2017, 9; Curtice, 2017; Hobolt,
2016). Nonetheless, gaps remain in our knowledge. Brexit was as much a process as an event, therefore requiring both a deepening and widening of understanding stretching back and beyond the casting of those fateful votes in the summer of 2016.

Although none of the five books under review offers a comprehensive account of Brexit, each provides valuable pieces of the jigsaw puzzle to help complete the picture of why Brexit happened and why the drama played out the way it did. The picture of Brexit requires analysis of its roots (sociology), the terrain (history), the nature of the central object (the referendum itself), the ideological lens through which some viewed the debate, and an understanding of the power of narratives.

\section{Identity and the Roots of Brexit}

The title of Maria Sobolewska and Robert Ford's insightful book is well chosen. Brexitland is less about Brexit and more about the land and its people who generated a decision to leave. For them, Brexit is more a symptom of a deeper malaise than the main focus of the book. "Britain did not become Brexitland on 23 June 2016.” Rather, they argue, "The people who ended up on opposite sides of the Brexit argument had been drifting apart for decades" (p. 217). The referendum, therefore, is "not so much a moment of creation" but rather a "moment of awakening" when the 
"social and political processes long underway finally became obvious" (p. 2).

The key division within Brexitland-between identity liberals and identity conservatives - was generated and reinforced by two significant changes to British society: immigration and educational expansion. Of these, the former is key to Sobolewska's and Ford's analysis. Immigration has long been an important theme in British politics, although its importance has waxed and waned. Its salience has been linked to the consequences of choices made by British politicians to welcome immigration, particularly the 1948 Nationality Act that accorded rights to Commonwealth citizens, the decision of the Conservative government to welcome the Ugandan Asians expelled by Idi Amin in the early 1970s, and the Blair government's decision not to impose restrictions on the citizens from the new member states of Central and Eastern Europe joining the EU in 2004. Each decision may have been noble and principled, but each also provoked a reaction among those with an ethnocentric worldview that sees one's own group as "the centre of everything" (p. 22). This Weltanschauung is "stable over time" but "becomes activated when ethnocentric voters perceive a threat" (pp. 38, 40; emphasis in the original). The importance of activation highlights that demography is not destiny. Demographic shifts may change the electoral resources available to parties, but it takes politicians like Enoch Powell or Nigel Farage to mobilize and make them politically significant.

Although immigration is the most significant issue in Brexitland, Sobolewska and Ford's cogent analysis goes deeper. They maintain that ideological convergence between the two main parties, combined with politicians being recruited from a limited number of professions, created representational strain. Voters responded to these changes "with growing disaffection and disinterest, reflecting a growing belief that they were being denied a meaningful choice" — a feeling only "exacerbated" by campaign strategies focused on target seats and swing voters that took for granted, and hence neglected, voters in safe seats (p. 9). The growing sense of disconnection was manifested in steep falls in partisanship, especially in the traditional Labour heartlands. As pollster Deborah Mattinson $(2020,74)$ has argued, immigration emerged as a "vortex" issue, a lens through which the many grievances that voters identified and felt, particularly the pressures on public services, could be explained. All these pressures, argue Sobolewska and Ford, came to a head in the referendum when the "restraining influences of party loyalties, local political cultures and first-past-thepost electoral incentives were removed" and "the latent identity divides in the electorate became fully mobilized as the primary factors structuring voters' choices" (p. 234).

Sobolewska and Ford's book is more convincing than attempts to see Brexit largely as a product of austerity
(Fetzer 2019).The roots of Brexit go much deeper, linked to a more volatile and disenchanted electorate. Indeed, Brexitland helps us better understand the fraying of bonds between ordinary citizens and politicians in recent times. Such a lack of linkage, of course, is not unique to the country that voted for Brexit and has been manifested in different ways in other established democracies.

Nevertheless, to understand the divisions of Brexitland we also need to add to the story two vital ingredients underplayed by Sobolewska and Ford: the referendum campaign itself (to which I return) and the European Union. Although the EU was never a particularly salient theme of politics before the referendum, it mattered for a slice of the electorate and a band of vocal Conservative MPs, activists, and supporters who were captivated by the idea that leaving the European club would somehow unleash the potential of an economy and society tied down and thwarted by Brussels bureaucracy: Britannia redux.

\section{A Thousand and Forty Years of History}

The great strength of Sobolewska and Ford's book is that it highlights how long-term societal changes created the raw materials for politicians to exploit, yet it also reminds us of the need for a longer historical perspective. Britain's complicated relationship with the process of European integration was profoundly shaped by historical experiences and Britain's place in the world (Wall 2020).

History is central to Beatrice Heuser's monograph, Brexit in History: Sovereignty or a European Union? In her provocative book, she takes aim at much of international relations scholarship (and even the name itself), the labels used by different schools such as realism and liberalism (although she is more sympathetic to the use of the term "constructivism"), and much interpretation (or misinterpretation) of what she prefers to label "inter-polity relations" from the Ancient Greeks onward. The struggles between France and the Germanic lands (in their various guises) form a running theme of the book, as are various noble schemes for peace in Europe dreamt up by a variety of figures over several centuries including Pierre Dubois, Jiř́ z Poděbrad, William Penn, and Abbé de Saint Pierre. All failed to achieve their goal of peaceful coexistence.

The title of Heuser's book is a misnomer. The reader might be lured into thinking this is a book about Brexit. Brexit does appear, but only fleetingly. Rather, Brexit in History is more a guide through the twists and turns of European history and the rivalries between states: as Heuser puts it, "the context of centuries of struggle about the European order" (p. 1). The chapter on the medieval system, for instance, provides fascinating detail and does cast doubt on the applicability of using the terms "realist" or "liberal" to explain inter-polity relations between 476 and 1453 , but it does not enhance much our understanding of why a small collection of islands off the northwest coast of Belgium chose to leave the EU in 2016. 
History, however, does matter. Some of the trends and developments charted by Heuser are important in explaining Brexit. Writing of the early eighteenth century, for example, Heuser notes that given the wars and struggles in Europe, "it is comprehensible in this context, as ships brought in ever more riches from around the world," that "Britons began to fancy the idea of splendid isolation of Britain from matters continental" (p. 131). Heuser is right that Britain's place in the world and Britons' views of that place have long animated discussions on involvement in European integration on the left, right, and center of British politics. When the Conservative government first applied for membership in the European Economic Community (EEC) in the early 1960s, for instance, thenLabour leader Hugh Gaitskell claimed that joining would bring an end to a thousand years of history.

Specifically, as Stephen Wall argues, memories of a particular aspect of Britain's history, its imperial past, "have exerted a powerful influence on Britain's European debate" (Saunders 2020). In his letter declaring his intention to campaign for "Leave," Boris Johnson conjured up the British Empire: "We used to run the biggest empire the world has ever seen, and with a much smaller domestic population and a relatively tiny civil service. Are we really incapable of cutting trade deals?" (Shipman 2017, 617). The empire not only left a demographic legacy, particularly the first wave of Commonwealth immigration from the 1950 s to the 1970s, but it also feeds into the politics of place and belonging, the reservoir of memory and misremembering. The Brexit vote and more recently Black Lives Matter have provoked wider debates about the role of the imperial past in the politics of the present. Recent books remind us of the bewildering complexity of the legacies, patterns, correlations, and echoes of empire that have left their mark on how Britons view and interact with inhabitants of different parts of the globe (Sanghera 2021).

The importance of placing seismic events like the Brexit vote into historical perspective is also at the heart of The Referendum in Britain. However unusual that June 23, 2016, referendum might feel, it was not as unique as it might appear at first glance. Except for a brief excursion on the conduct of the Brexit vote, the book is not concerned about the content of referendum campaigns. Rather it is about the idea of holding referenda. Lucy Atkinson and her coauthors serve up a detailed account that authoritatively navigates the reader through debates and disagreements stretching back to the late nineteenth century. They highlight that the earliest referenda were on issues like the formation of free public libraries or pub openings in Scotland and Wales and that the revival of their use in the 1970s was linked to territorial or sovereignty questions: the constitutional status of Northern Ireland (1973), Scottish and Welsh devolution (1979), and continued membership in the EEC (1975). They note that all three referendums led to the maintenance of the status quo, but once the tool was revived in the 1990s, some-but by no means all-were "vehicles for transformation" (p. 163), of which the Brexit vote was perhaps the most striking example. The contrast underlines a running thread throughout the book: several of those who advocated referenda saw them (sometimes mistakenly) not as an instrument for change but rather as a bulwark against it.

Although some will regard the largely chronological narrative flow as a major strength of The Referendum in Britain, others will lament the fact that the coauthors explicitly eschew theorizing. The reader is left knowing much more about the debates and discussions surrounding the decision to put an issue to a referendum or not, but less about when and why we might expect referenda to be called in the future and why some will be won and others lost.

\section{Role of the Campaign}

Historical experiences and demographic change help explain the terrain on which the battle was fought, but in a referendum, particularly one that delivered a relatively close outcome ( $52 \%$ vs. $48 \%$ ), we might assume that the campaign mattered or at least could have. Drawing on interviews with campaigners, media content analysis, and a detailed post-referendum survey, Ece Özlem Atikcan, Richard Nadeau, and Éric Bélanger's book not only places the 2016 referendum in comparative perspective but also provides a sophisticated analysis of the role of the campaign in determining the result.

Central to the success or failure of any referendum is the framing of the choice. "Leave" framed the debate in such a way that negated the usual status quo bias: its iconic and alluring "Take Back Control" slogan combined not just a sense of a positive future, albeit never defined or elaborated, but also suggested a sense of rightful ownership and the opportunity to return power to where it should belong. The book highlights the mistakes made on the "Remain" side. Drawing lessons from the Scottish referendum and the 2015 general election, Remain chose to frame the vote as an economic one. "But as the campaign unfolded, the Leave side effectively neutralized these economic arguments and de-risked a departure from the status quo" (p. 28; emphasis in the original). Pointing to the euro and migration crises and the possibilities of EU's expansion to include Turkey, the Leave side was able to portray remaining in the $\mathrm{EU}$ as a risk. Both sides, therefore, were invoking "Project Fear," but whereas the Leave side evoked a glorious-albeit unclearly defined-future outside the $\mathrm{EU}$, Remain was unable to provide a strong positive case for staying in the club. Decades of scapegoating the EU and the lack of prominent figures making a pro-European case under a succession of governments of different hues made attempts by politicians to start talking up the EU in 2016 sound hollow and insincere. 
Although Atikcan and coauthors' book provides an astute and sophisticated account nested in a deep comparative understanding of referenda, it is surprising that their analysis does not draw on or engage with more of the literature on campaigning, particularly the modes of campaigning and the balance between mobilization and conversion. Received wisdom of the campaign has tended to emphasize the importance of social media, the "Waterloo strategy" of spending large portions of funds close to polling day, and the infamous slogan on the side of a bus promising to give the National Health Service rather than Brussels $£ 350$ million a week (Shipman 2017, 418). But is that true? This book does not provide an answer. Moreover, given the kinds of societal divisions highlighted by Sobolewska and Ford, it is perhaps no surprise that the evidence points to only a small number of citizens changing their minds as a result of the campaigns. The 2016 referendum was a campaign not to convert, but to mobilize. At its heart the Leave vote was not a vote for a specific outcome; rather it was a vote against. Brexit in this light is best seen as an empty signifier, "initially successful in mobilizing and uniting a disparate, but often unconnected, range of discontent to its cause" from both the Right and the Left (Kettell and Kerr 2020, 592).

\section{A Leap (of Faith) to the Left}

Although Sobolewska and Ford's emphasis on the distinction between identity liberals and identity conservatives as the basis of the Remain and Leave camps explains much of the content and conduct of Brexit, the more traditional left-right spectrum still mattered in 2016. Throughout debates over membership in the EU from the mid-1960s onward-particularly during the 1975 referendum on continued membership - supporters of European integration were clustered in the center, with opponents of Britain's involvement congregated on the Left and the Right. The critique from the Left was always that the EU was a capitalist club, prioritizing profits over people, and a slice of opinion during the 2016 referendum, including Richard Tuck, made The Left Case for Brexit.

Tuck's book is a series of essays written largely postreferendum except for the eponymous essay. Richard Tuck is an acclaimed political theorist of scholars like Hobbes. In his thoughtful and clearly argued case highlighting the constraints rather than the opportunities of EU membership, Brexit did not offer up a future vision that would be nasty, brutish, and short but rather one full of possibilities. Freed from the shackles of Brussels, Britain's newly empowered Parliament would be able to channel the desires of the working class into building a socialist paradise.

It is certainly true that the EU acts as a constraint. It restricts member state actions by laying down the parameters of the possible, and the economic basis of the European project is a market one. Brussels would not allow everything Tuck would want, and in that sense the "Lexiteer" case is right. But removing restrictions does not determine the direction of travel: Brexit facilitates not just more left-wing policies but also more right-wing ones. Tuck's vision is predicated on a Labour victory at the polls, but the only time Labour has secured a healthy majority in the past half-century was in the Blair years-and for Lexiteers, Tony Blair is a bette noire, a target of scorn to be lambasted even more than Margaret Thatcher.

Tuck acknowledges that England is a fundamentally conservative country and that the chances of socialism being implemented are contingent on the continuation of the United Kingdom. But this is where Tuck's argument starts to look decidedly shaky. He claims that "only a full Brexit is likely to slow down or even stop the slide towards Scottish independence, since only it introduces real costs to the process" (p. 166). How you see things depends not just on where you sit but also when you pronounce judgment. From the vantage point of spring 2021 just after the Scottish Parliament elections in which a majority of the newly elected MSPs supported independence, the chances of Scotland leaving the United Kingdom look quite high. What might save the union will not be a widespread clamoring for socialism but the logistical headaches of divorce. If the exit of the United Kingdom from a four-decade (European) union has proved to be messy and fraught, the extrication of Scotland from the 300-year union with England would be magnified several-fold.

Scotland receives much coverage in several of the books under consideration. Sobolewska and Ford, for instance, offer a chapter on Scotland mostly focused on highlighting differences in the Scottish referendum, particularly in how identity politics played out. But they offer less on England explicitly: English nationalism gets a mention in their conclusion, but it was much more central to the story of Brexit than has been often acknowledged. Fintan O'Toole $(2020,382)$ goes too far in claiming that "Brexit has never really been about the EU. Brexit is about England and its deep unhappiness with itself," but the English dimension should not be ignored. As Ailsa Henderson and Richard Wyn Jones $(2021,82)$ show, people in England who felt "predominantly or exclusively English" were "significantly more likely" to vote Leave than those who identified as "predominantly or exclusively British." English nationalism is characterized by an unstable referent object: England within the state, but Britain without. This nationalism "manifests itself through a valorization of an idealized past; a sense of grievance about England's allegedly unfair treatment within a post-devolution UK; and resentment at the perceived undermining of Britain's sovereignty and status as a result of EU membership" (167).

\section{Narratives, Numbers, and Negotiations}

Britons may have voted to leave in May 2016, but that in itself does not explain the United Kingdom's 
departure with a hard rather than soft Brexit. The difference between the hard and soft variants was mostly over participation in the Customs Union and the Single Market. Faced with the spectrum of possible Brexit outcomes, argue Sobolewska and Ford, the new government led by Theresa May "focused on the 'harder' forms of Brexit which were most acceptable to identity conservatives, delivering maximal national sovereignty and control of immigration" (p. 288). Moreover, the actual departure was facilitated by losers' consent. There was what Atikican and coauthors describe as a "crucial reservoir of support" of some Remainers that played a key role in "consolidating the legitimacy of the referendum" (p. 152) despite the entrenched divisions in public opinion and a pro-EU grassroots mobilization against Brexit sparked by the referendum (Galpin 2021).

The books under review, however, do not place enough emphasis on the power of language and the discursive framing of Brexit in the period after the referendum (Brusenbach Meislova 2019). Brexit, especially the type of hard Brexit we eventually saw, can be explained in nine words and three slogans: "Take Back Control," "Brexit Means Brexit," and "Get Brexit Done." The referendum's endorsement of "Take Back Control" had underscored the need to wrest control from Brussels, especially over our money, law. and borders. But what did that mean in practice? David Cameron's resignation prompted a leadership battle marked more by a catalog of gaffes and backstabbing than scrutiny of the different candidates' visions for Brexit. Theresa May was soon the only person left standing and "avoided being forced to define, defend and win party backing for her vision of Brexit" (Rutter and Menon 2020).

The new prime minister coined her own slogan: "Brexit Means Brexit." It was sufficiently vague to satisfy the majority of Leave supporters and initially rally her party behind her, but it also indicated that the direction of travel was clear. Brexit would happen because the vote of the 17.4 million to leave the EU had to be respected. "Brexit Means Brexit," however, made negotiations with the EU tricky, not least because the EU side did not know what the UK wanted (Barnier 2021). Tautology was never going to be the basis for long-term agreement. As part of the negotiating strategy, several leading Conservatives, including May herself, stressed that any old deal would not do. No deal, they suggested, would be better than a bad deal. This might have been a useful tool for UK-EU negotiations to extract better terms for Britain, but May was involved in two-level negotiations, and it was the negotiations with members of her own party that caused her more anguish. When agreements were struck in Brussels, the hardliners in her own party labeled them the kind of bad deal that May and others had been warning about, helping inflict large and humiliating parliamentary defeats that led to her resignation (Kettell and Kerr 2020, 593).

Boris Johnson sought to rally his party and the electorate to his promise to "Get Brexit Done." Johnson's slogan offered the British people, who had been subject to years of interminable wrangling and inconclusive parliamentary votes, the prospect that this wrangling could all be over and done with. With eight out of ten Britons by late 2019 fed up with seeing Brexit on the TV news night after night (Mattinson 2020,113), Johnson's duplicitous claim of having an oven-ready deal was a message that appealed not just to Brexiteers but also to reluctant, resigned, and exhausted Remainers.

Johnson's victory in December 2019's election was followed shortly after by the United Kingdom's formal departure from the EU, but for much of the remainder of 2020 negotiations continued to find the basis of long-term future cooperation. If this was oven ready, it appeared, at best, designed for a slow cooker. Thorny issues related to fair competition and fish dominated the discussions, although these were influenced and, at times, overshadowed by the coronavirus pandemic, the consequences of which will affect the impact and perception of Brexit.

The most significant impact of Brexit may be to the United Kingdom itself. Not only has it fueled support for Scottish independence but also the future of Northern Ireland (which was barely mentioned in the campaign) appears far from settled. Perhaps the greatest legacy of Brexit, therefore, will be to create exits from Brexitland itself.

\section{References}

Barnier, Michel. 2021. La Grande Illusion: Journal secret du Brexit (2016-2020). Paris: Gallimard.

Brusenbach Meislova, Monika. 2019. "Brexit Means Brexit—or Does It? The Legacy of Theresa May's Discursive Treatment of Brexit." Political Quarterly 90 (4): 681-89.

Clarke, Harold D., Matthew Goodwin, and Paul Whiteley. 2017. Brexit: Why Britain Voted to Leave the European Union. Cambridge: Cambridge University Press.

Curtice, John. 2017. "Why Leave Won the UK's EU Referendum." Journal of Common Market Studies 55 (s1): 19-37.

Fetzer, Thiemo. 2019. "Did Austerity Cause Brexit?" American Economic Review 109 (11): 3849-86.

Galpin, Charlotte. 2021. "Contesting Brexit Masculinities: Pro-European Activists and Feminist EU Citizenship." Journal of Common Market Studies. https://onlinelibrary.wiley.com/doi/10.1111/ jcms.13216. 
Henderson, Ailsa, and Richard Wyn Jones. 2021. Englishness: The Political Force Transforming Britain. Oxford: Oxford University Press.

Hobolt, Sara B. 2016. "The Brexit Vote: A Divided Nation, a Divided Continent." Journal of European Public Policy 23 (9): 1259-77.

Kettell, Steve, and Peter Kerr. 2020. "From Eating Cake to Crashing Out: Constructing the Myth of a No-Deal Brexit." Comparative European Politics 18: 590-608.

Mattinson, Deborah. 2020. Beyond the Red Wall: Why Labour Lost, How the Conservatives Won and What Will Happen Next. London: Biteback.

O'Toole, Fintan. 2020. Three Years in Hell: The Brexit Chronicles. London: Head of Zeus.
Rutter, Jill, and Anand Menon. 2020. "Who Killed Soft Brexit?” Prospect, November 9. https://www. prospectmagazine.co.uk/magazine/who-killed-softbrexit-eu-european-union-no-deal.

Sanghera, Sathnam. 2021. Empireland: How Imperialism Has Shaped Modern Britain. London: Viking.

Saunders, Robert. 2020. "Brexit and Empire: 'Global Britain' and the Myth of Imperial Nostalgia." Journal of Imperial and Commonwealth History 48 (6): 1140-74. Shipman, Tim. 2017. All Out War: The Full Story of Brexit, revised ed. London: William Collins.

Wall, Stephen. 2020. Reluctant European: Britain and the European Union from 1945 to Brexit. Oxford: Oxford University Press. 